Chairman: SURGEON VICE ADMIRAL SIR ALEXANDER INGLEBYMACKENZIE, K.B.E., C.B., B.M., B.CH., M.R.C.S., L.R.C.P., Q.H.P., MEDICAL Director general, ROYAl Navy, Medical Department of the Royal Navy (Admiralty),

Queen Anne's Mansions, St Fames's Park, London, S.W. I

\title{
Chairman's Opening Address
}

\section{JAMES LIND}

By A. Ingleby-Mackenzie, Medical Department of the Royal Navy (Admiralty), Queen Anne's Mansions, St Fames's Park, London, S.W. I

During the eighteenth century Britain was engaged in many wars-and as in all wars men of all callings were mobilized to man the ships and fill the ranks of the soldiery.

In October 1739, when Britain and Spain went to war, great adventures were to befall many men and certain sparks were to be kindled in some of them when fanned by currents of adversity to illuminate the highest attributes of courage, clear thinking and humanity.

Amongst the many adventurers and patriots who left their Scottish homes to join the enlarging fleets in the south was a young man of 23 , an apprentice to an Edinburgh surgeon.

This young man, James Lind, the son of a merchant and burgess of Edinburgh and brother of a serving naval officer, with the benefit of his skilled training, made application and joined the Royal Navy as a surgeon's mate. Thus he began an association with this Service which was to last a lifetime.

Tobias Smollett, a compatriot and surgeon's mate as well, amply aired his feelings through Roderick Random on the lot of a surgeon's mate. Some considered much exaggeration and caricature was exhibited in his chronicle, but was it really difficult to stretch the imagination on the way of life at sea during that period?

Lind's service afloat in the ships Centurion and Salisbury left him in no doubt of the reality of the ravages of sea diseases-which he regarded as distinct occupational hazards of that day. In the preface to the first edition of his tract on scurvy (Lind, 1753) he stated: 'the scurvy alone, during the last war, proved a more destructive enemy, and cut off more valuable lives, than the united efforts of the French and Spanish Arms'.

For three centuries before Lind's time, during the period of the development 
of the sailing ship which made long ocean voyages possible, scurvy was as universal a disease of sailors as smallpox was of the landsman, without the associated immunity factor to attenuate repeated attacks.

The hardships which sailormen experienced during Anson's voyage in $174^{\circ}$ kindled the desire in Lind to study and alleviate the calamities which befell seamen on extensive exploratory and campaign voyages. In consequence he dedicated his first great work to Lord Anson.

A brief report of this epic sea saga tells us that:

On I8 September, 1740 , eight vessels, with a total complement of 1500 souls, left England on an expedition to the West Coast of South America and the Pacific. The Commodore of the Squadron, Captain George Anson, wore his flag in the Centurion.

Anson's orders were to proceed to the Spanish Coast of the South Seas, to attack and harass the Spanish everywhere, at sea or on land; to seek the friendship of the natives of Chile and to enlist them as allies against Spain; to attack Callao and to destroy Panama. His final instructions were to return home either by Cape Horn or by the Cape of Good Hope.

In spite of deficiencies in complement and equipment, the mission was successfully accomplished by a small band of men who braved tempest, shipwreck, sickness and battle.

The squadron rounded Cape Horn early in $174 \mathrm{I}$. By May of that year, sickness had caused the death of half the Centurion's ship's company, and the other ships fared no better. In fact, in the harbour of Juan Fernandez, Selkirk's Robinson Crusoe island, Anson abandoned two of his larger vessels and transferred the remains of their crews to bring the complement of the Centurion up to full strength. On 20 June 1743 , after a fierce battle, Anson completed his mission by capturing the large Spanish Acapulo galleon. He took his prize and prisoners to Canton, and then set sail for England in December I743, and anchored off Portsmouth 6 months later.

While at sea in the Salisbury, Lind began experiments which convinced him of the best course of treatment to pursue for scurvy. He selected twelve patients all having the same symptoms of scurvy, and all in the 'proper apartment for the sick in the fore-hold'. The diet was the same in each case.

Breakfast: water gruel sweetened with sugar.

Dinner: fresh mutton broth, or light puddings or boiled biscuits with sugar.

Supper: barley with raisins, rice and currants, sago and wine.

Two men received I quart of cider daily.

Two men received twenty-five drops of elixir of vitriol thrice daily on an empty stomach and used a mouth wash and gargle.

Two men received two spoonfuls of vinegar three times a day on an empty stomach, and again the mouth wash and gargle.

Two men received $\frac{1}{2}$ pint of sea water three times a day. 
Two men received a concoction of garlic, mustard seed, horseradish, gum myrrh and balsam of peru, barley water and tamarinds to drink, with cream of tartar, all this again three times a day.

Two men received two oranges and one lemon daily, for 6 days only.

The results were, according to Lind, favourable to those who took the citrus fruits, as these men improved with astonishing rapidity. Next best came the cidertreated cases. The elixir of vitriol was considered useful only for local treatment.

For a young doctor, at sea, spurred on by an idea, under the conditions on shipboard of that day, who can deny tribute to the adventuresome and scientific spirit of the man?

In 1748 , the European war ended with the peace treaty of Aix-la-Chapelle, and Lind ceased active service to return home. In May of that year he was granted the M.D. of Edinburgh and later began a private practice. During the next ro years he played a prominent part in medical circles; he was admitted a Fellow of the Royal College of Physicians of Edinburgh in $175^{\circ}$ and he became Treasurer of the College in 1756. During that period he published his two great books, $A$ Treatise of the Scurvy (Lind, 1753) and An Essay on the Most Effectual Means of Preserving the Health of Seamen in the Royal Navy (Lind, 1757).

In the treatise, Lind considered fully the history, nature, causes and cure of scurvy. The book contains a considerable chronological list, a Bibliotheca Scorbutica, of all writings on the subject from 1534 . He credits the Dutch physician of Gouda, Ronsseus (1564) (see Lind, 1753), with employing oranges and lemons as a cure for scurvy. He noted that in 1593 Sir Richard Hawkins had protected his crew in the Dainty by employing the same fruits. In I600, Commodore James Lancaster, of the East India Company, had made successful voyages to the Cape, and this sailor also emphasized the use of lemon juice.

Lind frankly pointed out that he was not the originator of the citrus fruit idea, but its staunch advocate. Further, he said that these substances were not the whole prescription for the prevention of scurvy. He considered that overcrowding, dampness and generalized depression of spirits were also contributory factors in the spread of the disease.

What Lind saw clearly is commonplace to-day. His teachings provided for the strength of the Royal Navy to be maintained, and gave his successors a substantial background against which to continue, during times of war and peace, the practice of the science and art of preventive medicine in a marine environment.

Lind left Edinburgh in $175^{8}$ to take up the appointment of Physician in Charge of the Royal Naval Hospital at Haslar, an appointment he held for 25 years, to be succeeded in office by his son John.

During his first 2 years at Haslar there were 5743 in-patients of which 1146 were scurvy cases. During the period of the Seven Years' War (1756-63) it was quite usual for the Channel Fleet to arrive at Spithead to discharge to Haslar anything from 1000 to 2000 cases of scurvy.

Of the more shining examples of adherence to the hygienic principles advocated by Lind can be included the chronicle of Sir Edward Hawke, who, in command 
of a British fleet in $\mathbf{1 7 5 9}$, blockaded the French off Brest. He gained the victory of Quiberon Bay, and during the several months of the blockade, he insisted on supplies of fruit and vegetables being sent to him regularly from England. To his acceptance of Lind's advice it may be credited that of the 14,000 men under Hawke's command, there were not twenty men sick on the day of the decisive battle.

His successors, Sir Gilbert Blane and Thomas Trotter, both understood Lind's meritorious probings. When Blane corroborated the work and teaching of Lind in his own Observations on the Diseases Incident to Seamen (Blane, 1785) and was later, in 1795, appointed Commissioner for the Sick and Wounded and Chief Officer of the Navy Medical Board under the Admiralty, he instituted all the reforms which Lind had advocated. Early in 1796,2 years after Lind died, the order was promulgated which allowed every man of the fleet an issue of lemon juice as a prophylactic against scurvy. In so doing, Blane gave full credit to Lind's efforts and shortly after the order came into force cases of scurvy diminished rapidly in the official returns.

It is of interest that when Earl Spencer, First Lord of the Admiralty, visited Haslar Hospital in $\mathbf{1 7 9 7}$, he asked to see a case of scurvy, but was told that there was no case in the hospital which he could be shown!

Many great captains of that century lived, navigated, explored, devised strategy, fought and campaigned and experienced many difficulties of their profession as did Lind in his particular calling. But in his case it was without the honours of national glory which were bestowed on so many others. Strangely enough he did not seek honours. Rather, he demonstrated his strength in his writings and in influencing his colleagues by example and persistence in the laborious task of establishing the concept of preventive medicine and the practice of hygienic measures in the navy afloat and ashore. He personally did not witness the full and ripe fruit of his labours, though he must have viewed with satisfaction the successful course and progress of Cook's last two voyages under medical precautions based upon his own dogmata. He must have realized too, before his death, that his successors in office were very ready to continue to nourish the germinating seed of hygienic concepts which he had planted, pruning and shaping the sapling, and adding the warmth of their personal experience and influence to strengthen the roots of this delicate structure.

Sir John Simon (1890) wrote in his memorable English Sanitary Institutions a succint resumé of the object of this address which emphasizes that it is due to Lind that scurvy, which used to cripple fleet after fleet, and which used to waste thousands and thousands of the bravest lives, has since the days of Anson's expedition become an almost forgotten disease. To Lind therefore, even thus far, we owe as much saving of human life as probably to no other man except perhaps the discoverer of vaccination. 
Blane, G. ( $\left.7_{7} 85\right)$. Observations on the Diseases Incident to Seamen. London: J. Murray.

Lind, J. (1753). A Treatise of the Scurvy, Ist ed. Edinburgh: Sands, Murray and Cochran for A. Kincaid and A Donaldson.

Lind, J. (1757). An Essay on the Most Effectual Means of Preserving the Health of Seamen in the Royal Navy, London: A. Millar.

Lind, J. (1768). An Essay on Diseases Incidental to Europeans in Hot Climates. London: T. Becket and P. A. De Hondt.

Simon, J. (1890). English Sanitary Institutions. London: Cassell and Co.

\section{The Sheffield Experiment on the Vitamin C Requirement of Human Adults*}

\section{By H. A. Krebs, Medical Research Council Unit for Research in Cell Metabolism, Department of Biochemistry, University of Sheffield}

In 1938 the League of Nations Technical Commission on Nutrition estimated the daily vitamin $\mathrm{C}$ requirement of human adults at $30 \mathrm{mg}$ (League of Nations Health Organization: Technical Commission on Nutrition, 1938). In 1943 the (U.S.A.) National Research Council Committee on Food and Nutrition recommended an allowance of $75 \mathrm{mg}$ (National Research Council: Food and Nutrition Board, 1943). Some authorities, e.g. Zilva (194r, 1944) put the daily requirements much below $30 \mathrm{mg}$.

These were the main data on which dietary planning had to be based during the war years. The divergences in the estimates arose from the different standards used in assessing the requirement. The high values were based on studies of the saturation of the body with vitamin $\mathrm{C}$, whereas the lower values were inferred from observations on the prevention and cure of the clinical manifestations of scurvy. The differences were also an indication of the lack of accurate information, and in 1944 Professor R. A. Peters suggested to the Medical Research Council that it would be worth while obtaining additional information on the vitamin $\mathrm{C}$ requirements of human adults by a trial on human volunteers who had offered themselves for this kind of investigation at the Sorby Research Institute at Sheffield. Professor Peters's suggestion was accepted and the Vitamin C Subcommittee of the Medical

* This is a summary of the main aspects of the trial conducted by the Vitamin C Subcommittee of the Accessory Food Factors Committee of the Medical Research Council. Members of the Committee were R. A. Peters (Chairman), K. H. Coward, H. A. Krebs, L. W. Mapson, L. G. Parsons, B. S. Platt, J. C. Spence, J. R. P. O'Brien (Secretary). Others taking part were A. E. Barnes, W. Bartley, I. M. Frankau, G. A. Higgins, E. M. Hume, J. Pemberton, G. L. Roberts, H. Scarborough, H. R. Vickers, J. Waterlow and W. J. W. Ferguson. A full account of the trial is published by H.M. Stationery Office (Bartley, Krebs \& O'Brien, I 953). This Report includes reproductions of colour photographs of the pathological conditions seen during the trial. (See also Medical Research Council: Vitamin C Subcommittee of the Accessory Food Factors Committee, I948.)

The colour plates I to VI illustrate some of the clinical findings made during the trial.

The author is indebted to the Controller of H.M. Stationery Office for permission to produce this summary and for the use of illustrations taken from the Report. 